\title{
Effect of Magnetic Field on Diesel Engine Power Fuelled
}

\author{
with Jatropha-Diesel Oil \\ Sukarni Sukarni ${ }^{1, *}$, Partono Partono ${ }^{1}$, Deni Krisdianto ${ }^{1}$, and Retno Wulandari ${ }^{1}$ \\ ${ }^{1}$ Center for Renewable and Sustainable Energy Engineering, Department of Mechanical Engineering, Faculty of \\ Engineering, State University of Malang, Indonesia \\ Corresponding author: *sukarni.ft@um.ac.id
}

\begin{abstract}
Jatropha oil has characteristics very close to the diesel fuel, so it has good prospects as a substitute or as a mixture of diesel fuel. Previous research showed that jatropha oil usage in diesel engines caused power to decrease. It was probably owing to the higher viscosity of the Jatropha oil compared to that of diesel oil. Installing the magnetic field in the fuel line of a diesel engine fueled with jatropha-diesel oil is expected to reduce the viscosity of jatropha-diesel oil mixture, hence improve the combustion reaction process. This research aims to know the influence of the magnetic field strength in the fuel lines to the power of diesel engines fueled with a mixture of jatropha-diesel oil. The composition of Jatropha oil-diesel was $20 \%$ jatropha oil and $80 \%$ diesel oil. Magnetic field variations were $0.122,0.245$ and 0.368 Tesla. The results showed that the higher the strength of the magnetic field was, the higher the average diesel engine's power would be.

Copyright (C) 2017Journal of Mechanical Engineering Science and Technology

All rights reserved

Keywords: Diesel engine power, Jatropha oil, Magnetic field
\end{abstract}

\section{Introduction.}

The depletion of world oil reserves and the environmental pollution due to an increase in exhaust emissions have become major issues which call for prompt and apt actions, one of which is finding a suitable alternative fuel for diesel engines. Vegetable oil is a promising alternative fuel due to its renewable, environmentally friendly, and easy to produce in rural areas [1]. In addition, its chemical and physical properties are similar to diesel oil [2]. One source of non-food vegetable oil potential for diesel fuel is jatropha oil.

Even so, the use of jatropha oil as diesel engine fuel is encountered several drawbacks. Jatropha oil has a higher viscosity than diesel oil, making it difficult to atomize in the combustion chamber. The high viscosity of Jatropha oil is due to the presence of glycerol in the backbone of its chemical structure [3]. Moreover, its high viscosity is caused by its large molecular mass and chemical structures, which can cause problems in the pumping system, combustion and atomization in the diesel injection system [1]. Therefore, it is necessary to decrease the viscosity of Jatropha oil so that it can be used as a viable alternative fuel for diesel engines.

The problem owing to the high viscosity of vegetable oil has been addressed in several ways, such as preheating, mixing or diluting with other fuels, transesterification, and thermal cracking or pyrolysis [1]. In fact, it is common to mix vegetable oil with diesel fuel. Previous research has revealed that the greater the amount of jatropha oil in the mixture affected to the lower of engine power. The power generated from diesel engine fuelled with jatropha biodiesel oil is slightly smaller than the one with the use of diesel fuel; it is due to the lower calorific value of biodiesel [4]. The decrease in engine thermal efficiency with an increase in the proportion of jatropha oil is related to the incomplete combustion of jatropha oil because of high viscosity and low volatility $[1,5]$.

It is critical to improving combustion process of Jatropha oil in term of decreasing its viscosity. Giving magnetic field on jatropha fuel before entering the combustion chamber is one of the solutions to reduce the viscosity. The use of magnet established throughout the fuel flow pipe facilitates the binding of oxygen atoms by fuel during the combustion process [6].

There have been a number of researches on the influence of magnet on the characteristics of the fuel. Research conducted by Chalid, et al. [7] examined the effect of magnetic dipole system on the 
characteristics of kerosene. The results showed that the addition of a magnetic field of 4330 Gauss with 60 minutes magnetization increased the refractive index (from 1.447 to 1.449) and decreased the viscosity level from 1.278 to 1.256 . In other words, it raises the possibility of de-clustering reaction between molecules as well as an increase in the polarity of the molecules of kerosene. Tung et al. [8] investigated the relationship between magnetization and viscosity of crude oil containing a big amount of paraffin. The results showed that there was a decrease in viscosity due to magnetization.

There is a considerable amount of literature on the use of magnetic field on the fuel line of diesel engines. Sudrajat and Hendratna [9], for instance, have conducted research on the effect of a portable magnet on the fuel line to the temperature of exhaust gas and fuel consumption of a direct injection diesel engine fuelled with marine diesel. It is found that fuel consumption decreased by 13$14 \%$ under normal load conditions. A previous study by Siregar [10] has investigated the influence of coil wire diameter of energy-saving electromagnetic devices to the performance of diesel engines. The results showed that the use of wire with $0.35 \mathrm{~mm}$ diameter and 4000 windings offered fuel savings of approximately $30.79 \%$. Furthermore, Wahyudi [11] utilized an inducer in the form of the magnetic field from solenoids with 1000 and 2000 windings. As a result, there was an increase in power and decrease in fuel consumption.

The present research was conducted to determine the effect of variations in magnetic field strength on the fuel line to the engine power fuelled with jatropha-diesel oil.

\section{Method}

In the initial stage, a coil from copper wire with $1 \mathrm{~mm}$ diameter and 400 windings was made. Then, it was electrified at $0.5,1.0$ and 1.5A subsequently. Magnetic field strength generated was measured using teslameter. The measurement was performed by placing the tip of the probe teslameter at the center of the coil. According to Chalid, et al. [7], the type of magnet used for fuel should be about 2000 to 4000 Gauss (0.2-0.4 Tesla), while some others recommended only up to 500 Gauss ( 0.05 Tesla) [6]. Furthermore, the magnetic field coil was mounted in the fuel line before entering the injection pump.

The next stage was mixing jatropha oil with diesel oil -4 liters Jatropha oil were mixed with 16 liters diesel oil in a container. An empty diesel fuel tank was then filled with the mixture.

The diesel engine was turned on until it reached the operating temperature. The power measurement was performed using the dynamometer test, measuring the braking torque. From the torque and engine speed recorded on the tachometer, power measurement can be done. It was performed 8 times at each variation in magnetic field strength and machine rotation. Power measurements were carried out at various machine rotations, i.e. 1300, 1600, 1900, 2200 and 2500 $\mathrm{rpm}$. The results of engine power measurements of variations in magnetic field strength and machine rotation were analyzed using two-way ANOVA.

The specifications of the diesel engine are the type of DWE $-47-50-\mathrm{HS}-\mathrm{Av}, 4$ strokes, 4 cylinders, $2164 \mathrm{cc}, 83 \mathrm{~mm}$ of cylinder diameter, $47 \mathrm{BHP}$ of maximum shaft power at $3200 \mathrm{rpm}$, 22:1 of compression ratio.

\section{Results and discussion.}

Results of measuring magnetic field strength of coil carrying a current of $0.5,1.0$ and $1.5 \mathrm{~A}$ subsequently are presented in Table 1. Based on the literature [6,7], the resultant magnetic field strength generated by the current-carrying coil was adequate to produce an effect on fuel.

Table 1. Measurement Results of Magnetic Field Strength

\begin{tabular}{cc}
\hline $\begin{array}{c}\text { Current } \\
\text { (Ampere) }\end{array}$ & Magnetic Field Strength (Tesla) \\
\hline 0,5 & 0,122 \\
1,0 & 0,245 \\
1,5 & 0,368 \\
\hline
\end{tabular}


Table 2. Analysis of Variations on Effective Power

\begin{tabular}{ccccccc}
\hline Source of Variation & $\begin{array}{c}\text { Sum } \\
\text { Squares }\end{array}$ & $\begin{array}{c}\text { Degree of } \\
\text { Freedom }\end{array}$ & $\begin{array}{c}\text { Mean } \\
\text { Squares }\end{array}$ & F Calculate & F Table & Sig. \\
\hline Magnetic field strength & 13.878 & 3 & 4.626 & 51.439 & 3.924617 & 0.000 \\
Machine rotation & 5459.067 & 4 & 1364.767 & 15175.371 & 3.456075 & 0.000 \\
Magnetic field strength* & 111.604 & 12 & 9.300 & 103.414 & 2.314158 & 0.000 \\
machine rotation & 12.591 & 140 & 0.090 & & & \\
Error & 5597.140 & 159 & & & & \\
Total & & & & & & \\
\hline
\end{tabular}

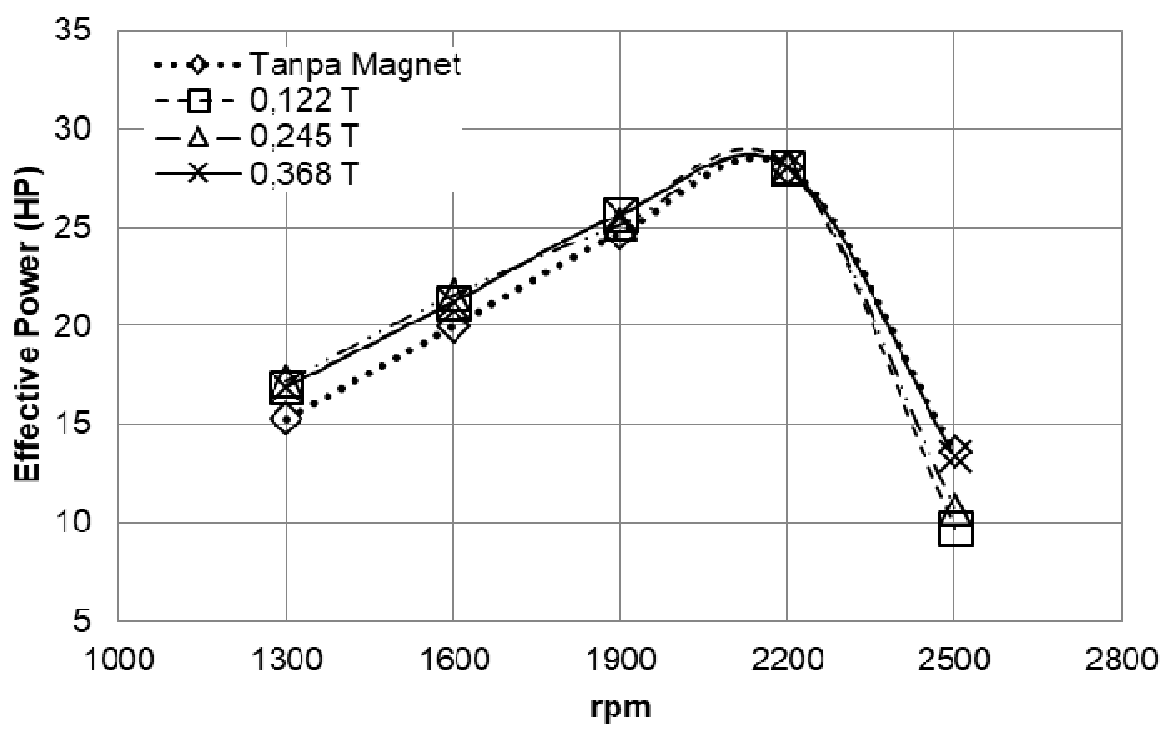

Fig. 1.Effective Powers of Variations on Magnetic Field Strength and Machine Rotation

Table 2 presents the results of two-way ANOVA test to determine the effect of variations in magnetic field strength and machine rotation, as well as to identify the effect of the interaction between magnetic field strength and the machine rotation on the effective power of diesel engine.

Table 2 shows how magnetic field strength affected effective power, the rotation affected effective power, and interaction between magnetic field strength and rotation affected effective power. Sudrajat dan Hendratna [9] pointed out that the use of magnet facilitated the process of ionization of engine fuel. Ionization is highly beneficial to facilitate the fuel in binding oxygen during the combustion process. The size of molecular structures of the fuel will transform into smaller bonds after the fuel is subjected to magnetization [12]. These smaller molecules result in the easier combustion process in the combustion chamber. In other words, the process of fuel magnetization will make a complete combustion. The more complete the combustion is, the greater the engine power will be.

The magnetic field generated the repulsive forces among hydrocarbon molecules so that the optimal distance between the hydrocarbon molecules will be formed; it will lower the hydrocarbon bond strength. As a consequence, the hydrocarbon molecules will be more reactive with oxygen and be more combustible, hence resulted in a complete combustion process. Better combustion resulted in better diesel engine performance [11].

The power generated from diesel engines in variations on magnetic field strength and rotation is shown in Figure 1.

The effect of magnetic field strength on the average power of the overall engine rotation is presented in Figure 2. 


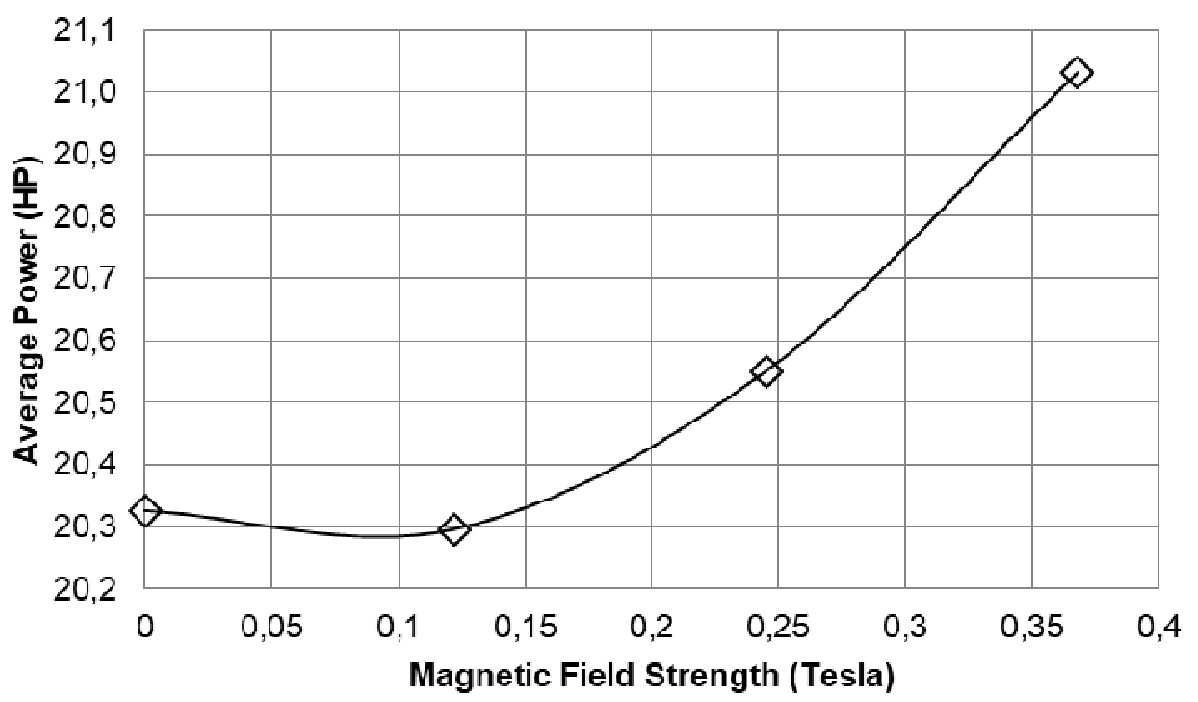

Fig. 2. Average Powers of Variations on Magnetic Field Strength

Figure 1 and Figure 2 suggested that the higher the magnetic field strength, the greater the engine power. This phenomenon was because of by the fact that an increase in magnetic field strength affected stronger repulsion among the molecules in the fuel, making the viscosity of the fuel at low rates. The decrease in viscosity led to a better fuel atomization in the injector, hence promoting a more completed combustion.

The phenomenon in which the viscosity level of the fuel dropped due to the influence of magnetic field strength has been explained by Chalid, et al. [7]. Hydrocarbon molecules tend to attract one another to form molecular clusters. As a result, they will not part ways when reacting with oxygen. A relatively strong magnetic field in hydrocarbon molecules results in the repulsion reaction between hydrocarbon molecules (de-clustering), so that optimal distance between the hydrocarbon molecules and oxygen are formed. Increasing the strength of magnetic field had a significant influence on improving the de-clustering effect. The strength of the magnetic field caused a change in electron density on atomic or molecular bonding region and increased the dipole moment thereby increased the polarity of molecules. Increasing the polarity had a strong relationship with the phenomenon of de-clustering due to an increase in the dipole moment on the bond among the molecules. Increasing the repulsion between the molecules led to a decrease in viscosity of the fuel, creating maximum distance between molecules of hydrocarbon and oxygen. As a result, fuel undergone magnetization reacts more easily during combustion, hence led to a higher engine power.

The effect of the magnetic field was significant at low rpm but tended to decrease as the rotation speed increased, and then disappeared at $2200 \mathrm{rpm}$ (as shown in Figure 1). It happened because a fuel flow tended to slow down at the low-speed rotation, meaning that it took longer time for fuel being exposed to the magnetic field. The higher the engine rotation, the shorter the impact of magnetic fields on fuel. It is in agreement with previous research conducted by Chalid, et al. [7], which revealed that the longer the fuel exposed to a magnetic field, the higher refractive index of the fuel. In other words, the longer the fuel affected to the magnetic field, the lower the viscosity level would be.

As illustrated in Figure 1, the faster the engine rotation, the higher the overall power. Theoretically, engine power is the function of engine rotation. Nonetheless, it was found that the highest power was reached at $2200 \mathrm{rpm}$ and subsequently the power decreased over $2200 \mathrm{rpm}$. The decreasing of power after reaching a peak at high speed $(2200 \mathrm{rpm})$ was owing to the higher friction losses [13].

At rotation rates above $2200 \mathrm{rpm}$, magnetic field adversely influenced the power, which made the engine power decreased. This was probably caused by fuel that was exposed to a magnetic field, making its viscosity value dropped and resulting in greater friction losses, e.g. dilute fuel can raise the friction between the piston and the cylinder wall. 
The maximum power generated in the test was far different from the standard specifications of the machine, where the maximum power is $47 \mathrm{BHP}$ occurring at $3200 \mathrm{rpm}$. The most likely explanation is that the machine was worn out; so that the friction losses increased significantly resulting in power generated was low, only up to $28 \mathrm{HP}$ at $2200 \mathrm{rpm}$ rotation.

\section{Conclusion.}

The results of this research have led to the conclusion that the magnetic field strength affects the power of diesel engine fuelled with a mixture of jatropha-diesel oil. The stronger the magnetic field, the higher the engine power. The maximum power increase of $12.76 \%$ occurred at $1300 \mathrm{rpm}$ with the magnetic field strength of 0.245 Tesla.

\section{References}

[1] Pramanik, K., "Properties and Use of Jatropha Curcas Oil and Diesel Fuel Blends in Compression Ignition Engine”, Renewable Energy, Vol. 28, Iss 2, 2003, pp. 239-248.

[2] Muniyappa, P. R., Brammer, S. C., and Noureddini, H., "Improved Conversion of Plant Oils and Animal Fats into Biodiesel and Co-Product”, Bioresource Technol., 56, 1996, pp. 19-24.

[3] Wardana, I.N.G., "Combustion Characteristics of Jatropha Oil Droplet at Various Oil Temperatures", Fuel, Volume 89, Issue 3, March 2010, pp. 659-664.

[4] Chakrabarti, M.H. and Ali, M., "Performance of Compression Ignition Engine with Indigenous Castor Oil Bio Diesel in Pakistan”, NED University Journal Of Research, Vol 10 VI, No. 1, 2009, pp. 10-19.

[5] Rao, T.V., Rao, G.B., and Reddy, K.H.C., "Experimental Investigation of Pongamia, Jatropha and Neem Methyl Esters as Biodiesel on C.I. Engine", Jordan Journal of Mechanical and Industrial Engineering, Volume 2, Number 2, Jun. 2008, pp. $117-122$.

[6] Magnetizer and Hydrocarbon Fuel, http:// www.magnetizer.com

[7] Chalid, M., Saksono, N., Adiwar dan Darsono, N., "Studi Pengaruh Magnetisasi Sistem Dipol terhadap Karakteristik Kerosin", Makara, Teknologi, Vol. 8, No. 1, April 2005, hal. 36-42.

[8] Tung, N.P., Vinh, N.Q., Phong, N.T.P., Long, B.Q.K. and Hung, P.V., "Perspective for Using Nd-Fe-B Magnets as Tool for The Improvement of The Production and Transportation of Vietnamese Crude Oil with High Paraffin Content", Institute of Material Science HCM City Branch NCST, Vietnam, 2004.

[9] Sudrajat, A. dan Hendratna, K.K., "Menghemat Bahan Bakar dengan Magnet Portabel". INOVASI Online, Edisi Vol.6/XVIII/Maret 2006. (Online) (http://io.ppi-jepang.org/article. php?id=145). Diakses 10 Juni 2009.

[10] Siregar, H. P., "Pengaruh Diameter Kawat Kumparan Alat Penghemat Energi yang Berbasis Elektromagnetik Terhadap Kinerja Motor Diesel”, Jurnal Teknik Mesin, Vol. 9, No. 1, April 2007, hal. $1-8$.

[11] Wahyudi, Lilik, "Studi Karakteristik Pengaruh Alat Penginduksi Elektromagnetik dari Solenoida untuk Menambah Sifat Reaktif Bahan Bakar Solar terhadap Unjuk Kerja Mesin Diesel", (Online) (www.etd.library.ums.ac.id/go.php?id=jtptums-gdl-s1-2006). Diakses 10 Juni 2009.

[12]Zarutskaya, T. and Shapiro, M., "Capture of Nanoparticles by Magnetic Filters", Journal of Aerosol Science, Volume 31, Issue 8, 2000, 907.

[13] Pulkrabek, W. W., Engineering Fundamentals of the Internal Combustion Engine, 2nd edition, Upper Saddle River, New Jersey: Prentice Hall, 2003. 